The effects of different levels of dietary protein ... (Nyoman Adiasmara Giri)

\title{
THE EFFECTSOF DIFFERENT LEVELSOF DIETARY PROTEIN AND LIPID ON THE GROWTH OF RED SNAPPER, Lutjanus sebae
}

\author{
Nyoman Adiasmara Giri \#, Ketut Suwirya, Muhammad Marzuqi, and \\ Ni Wayan Widya Astuti \\ Research Institute for Mariculture \\ JI. Br. Gondol Kec. Gerokgak Kab. Buleleng, Singaraja-Bali 81101
}

\begin{abstract}
Red snapper, Lutjanus sebae is favored in mariculture activities because it has a relatively good market and price. Technology for big scale seed production of this species has been developed and is now adequate to supply seed for grow-out activities. However, the availability of artifical diets for L. sebae is still a major constraint for grow- out production. Data on optimum dietary protein and lipid requirements for this fish as a basic information in feed development is not available yet. The objective of the present study was to find out dietary protein and lipid requirements for juvenile of L. sebae. A 70- day feeding experiment was conducted in 24 fiberglass tanks, 200 $L$ volume. Each tank was equipped with a flow-through water system. Twenty five hatchery-produced juveniles of L. sebae (43.1 g BW) were randomly selected and stocked in each tank. The fish were fed with the experimental diets twice everyday at a level of $3 \%$ of biomass for the first 4 weeks, and then $2 \%$ of biomass afterward. Twelve experimental diets were prepared in form of dry pellet containing casein and fish meal as the main protein sources. Experimental diet had 4 levels of crude protein $(32 \% 37 \% 42 \%$ and $47 \%$ and each protein level consisted of 3 levels of lipid $(7 \% 12 \%$ and $17 \%$. The experiment employed factorial method with completely random design using 12 combination treatments and 2 replications for each treatment. Result of the experiment showed that there was no significant effect of dietary protein and lipid on growth, feed consumption, and feed efficiency of tested fish. Growth and feed efficiency of fish fed on diet containing $42 \%$ and $47 \%$ crude protein were significantly higher than that of fish fed on diet containing $32 \%$ and $37 \%$ crude protein. High lipid content in the diet (17\%) resulted in poor growth and poor feed efficiency. This data indicates that Lutjanus sebae has limited ability to utilize dietary lipid as an energy source. Result of the present study recommends that dietary protein and lipid requirement for good growth of $\mathrm{L}$. sebae should be $42 \%$ and $12 \%$ respectively.
\end{abstract}

KEYWORDS: Lutjanus sebae, growth, dietary protein and lipid

\section{Introduction}

Red snapper, Lutjanus sebae is one of several favored species in mariculture industries. This fish is known as red emperor and inhabits tropical and sub-tropical waters. A series of research activities on the biological aspect and breeding behavior of red snapper was started in 2000 at the Research Institute for Mariculture, Gondol (Imanto \& Meliawati, 2003; Melianawati \& Imanto, 2004) and produced technology for mass production of seeds. With

\# Corresponding author. Research Institute for Mariculture, Jl. Br. Gondol, Kec. Gerokgak, Kab. Buleleng, Kotak Pos 140, Singaraja, Bali 81101, Indonesia. Tel.: + (0362) 92278

E-mail address: adiasmara@indosat.net.id 
the availability of seeds, the grow- out activity of this species could be started. However, one of the constraints in the grow- out activity for this species is the unavailability of suitable artificial feed. Red snapper is very selective to feed on artificial feed in form of dry pellet. The behavior of this fish, which is always active to move around, indicates that this fish requires a relatively high dietary energy. Energy is derived from dietary protein, carbohydrate and lipid. The ability of fish to utilize non protein energy sources will determine the efficiency of given feed, especially of dietary protein content for growth. The main constraint in developing artificial feed for red snapper is that there is not enough information on the dietary nutrient requirement for this fish. Dietary nutrient requirement for marine fish varies according to fish species. Protein requirement of grouper ranges from $47 \%-60 \%$ (Giri, 1998; Giri et al., 2002), red snapper, Lutjanus argentimaculatus of $40 \%$ (Giri et al., 2007) and 44\%(Catacutan et al., 2008), golden trevally, Gnathanodon speciosus of $42 \%-46 \%$ (Suwirya et al., 2008), and rockfish, Sebastes schlegeli of $42 \%$ (Lee et al., 2002). The effectiveness of protein utilization for growth by the fish is also determined by lipid. The results of some experiments suggested that some species of fish have limited ability in utilizing lipid as a source of dietary energy. There is a negative tendency that high lipid content in a diet will fail to stimulate the growth of fish (Lin \& Shiau, 2003; Williams et al., 2003). This study aimed to obtain information on dietary nutrient requirements, especially protein and effectiveness of the utilization of lipid for growth of fish, which then can be used for further development of effective artificial diets for red snapper.

\section{MATERIALS AND METHODS}

Experimental diet was prepared as dry pellet with 4 graded levels of protein content, namely $32 \% 37 \%, 42 \%$ and $47 \%$ and each level of dietary protein has 3 different lipid contents, which were $7 \% 12 \%$ and $17 \%$ Fish meal, squid liver meal, soybean meal and casein were the main sources of dietary protein, and dietary lipid derived from fish oil. Feed composition is shown in Table 1 and 2 . The experimental diet has a diameter of $5 \mathrm{~mm}$ produced using pellet machine "Royal Food Cutter, Japan". Pellets were then dried by using freeze dryer and finally stored in a refrigerator $\left(4^{\circ} \mathrm{C}\right)$ before and during the experiment. Juveniles of red snapper for the experiment were produced in the hatchery of Research Institute for Mariculture, Gondol. Juveniles from the hatchery were first kept in fiber tanks sized $2 \mathrm{~m} \times 2 \mathrm{~m} \times 0.75 \mathrm{~m}$ equipped with flow through water system and aeration and fed with dry pellet that was prepared in the Laboratory of Feed, RIM, Gondol. Experiment was conducted in the Wet Laboratory of the Research Institute for Mariculture, Gondol- Bali. Feeding experiment was conducted in 24 fiber glass tanks of $200 \mathrm{~L}$ volume. Each tank was equipped with aeration and flow- through water system. Sea water was first directed to flow through a sand filter before entering the experimental tank. Twenty five juveniles of red snapper with an average weight of $43.1 \mathrm{~g}$ were stocked in each tank. During the 98 days feeding experiment, fish were fed 2 times a day at 3\%of biomass during the first 4 weeks and then reduced to $2 \%$ of biomass afterward. The experiment was designed using a complete random design with factorial pattern consisting of 4 dietary protein levels and 3 levels of dietary lipid. Each treatment consisted of 2 replications. To know the response of fish fed on different experimental diets, all fish in each tank were weighed individually every 2 weeks. Proximate composition of experimental diet and fish were determined according to AOAC methods (1990). Growth rate, feed consumption, feed efficiency and survival of fish were statistically analyzed using ANOVA and Tukey test at significant level of 5\%(Steel \& Torrie, 1980).

\section{RESULTS AND DISCUSSION}

Average weight of fish for each treatment during the feeding experiment is shown in Figure 1 where growth of fish during the first 70 days feeding experiment was similar among all treatments. Only the weight of treated fish fed with the experimental diet containing $42 \%$ protein and $7 \%$ lipid was consistently higher up to the end of the feeding experiment compared to the other treatments. Meanwhile, slower growth was observed on all fish fed with high lipid contents (17\%) in all levels of dietary protein. Survival of red snapper up to the end of the experiment ranged from $76.7 \%$ to $82.7 \%$ As shown in Table 3, survival of fish was not affected by different contents of dietary protein or dietary lipid $(P>0.05)$. Bacterial infection on the eyes of fish was suspected as the main factor to contribute to the mortality of fish. Feed consumption was not influenced by different contents of dietary protein or dietary 
The effects of different levels of dietary protein ... (Nyoman Adiasmara Giri)

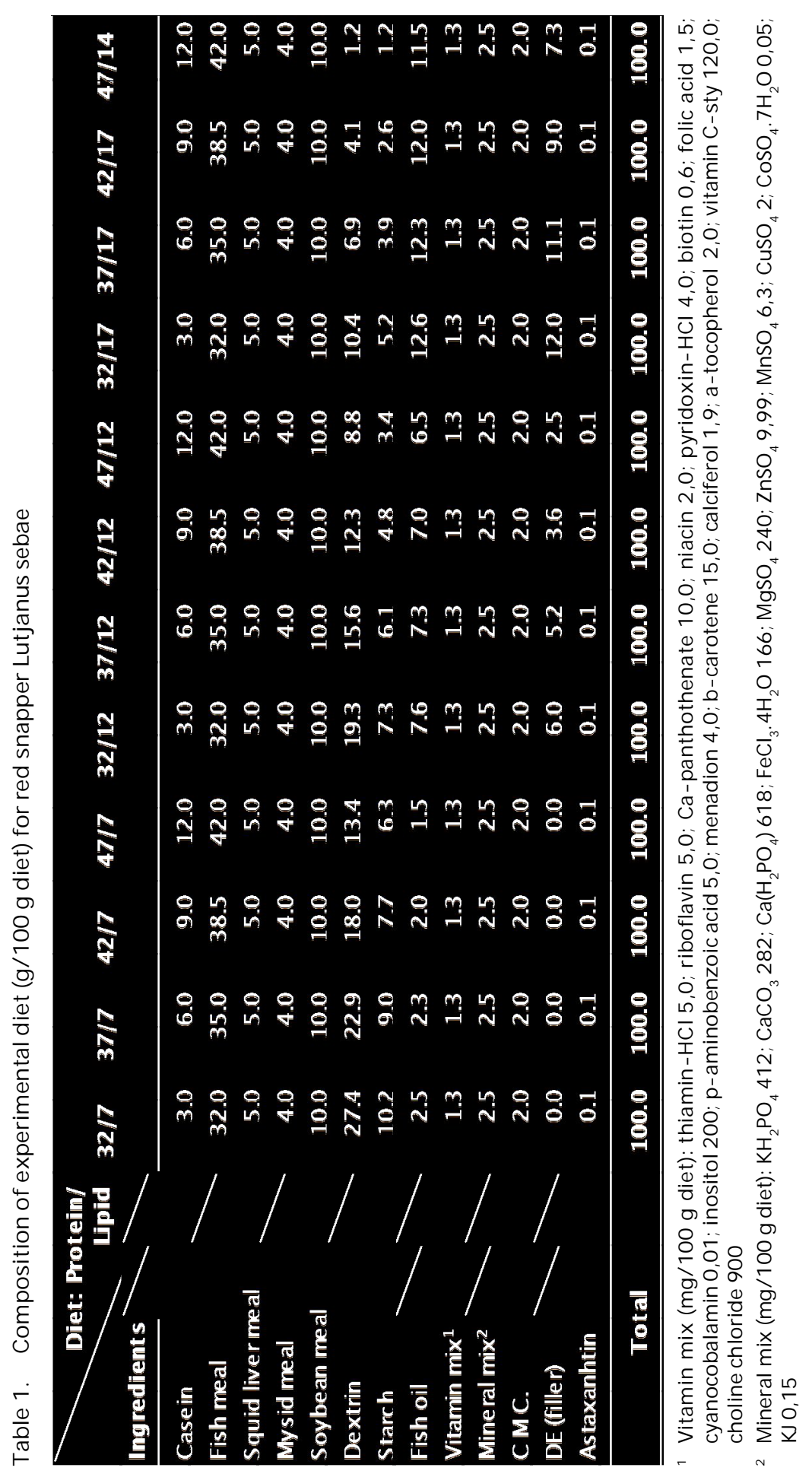




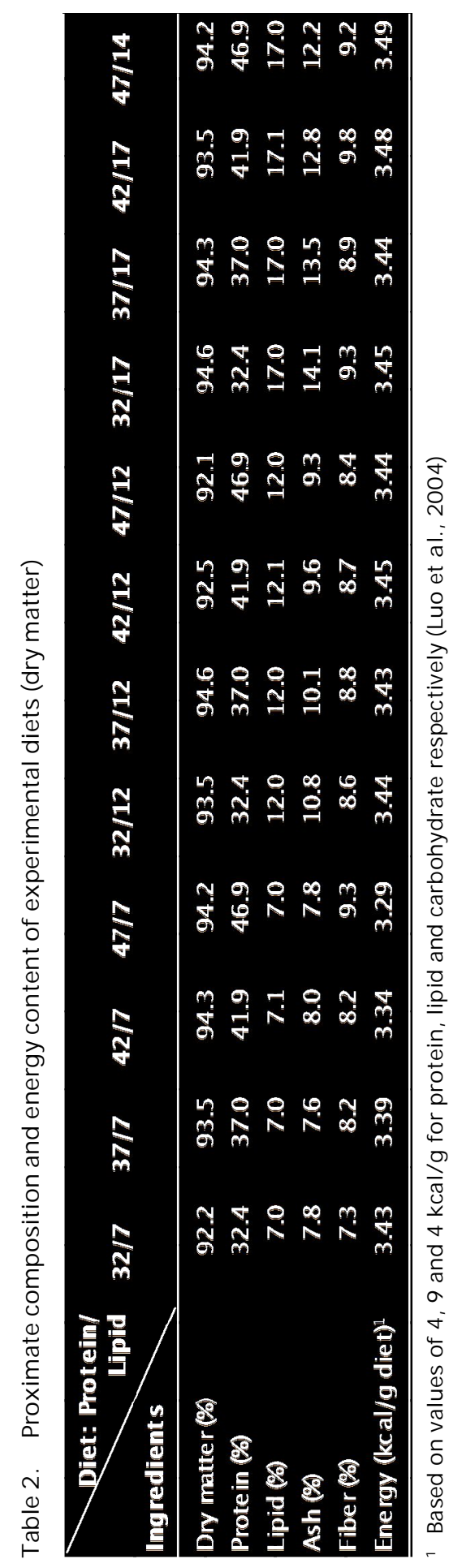


The effects of different levels of dietary protein ... (Nyoman Adiasmara Giri)

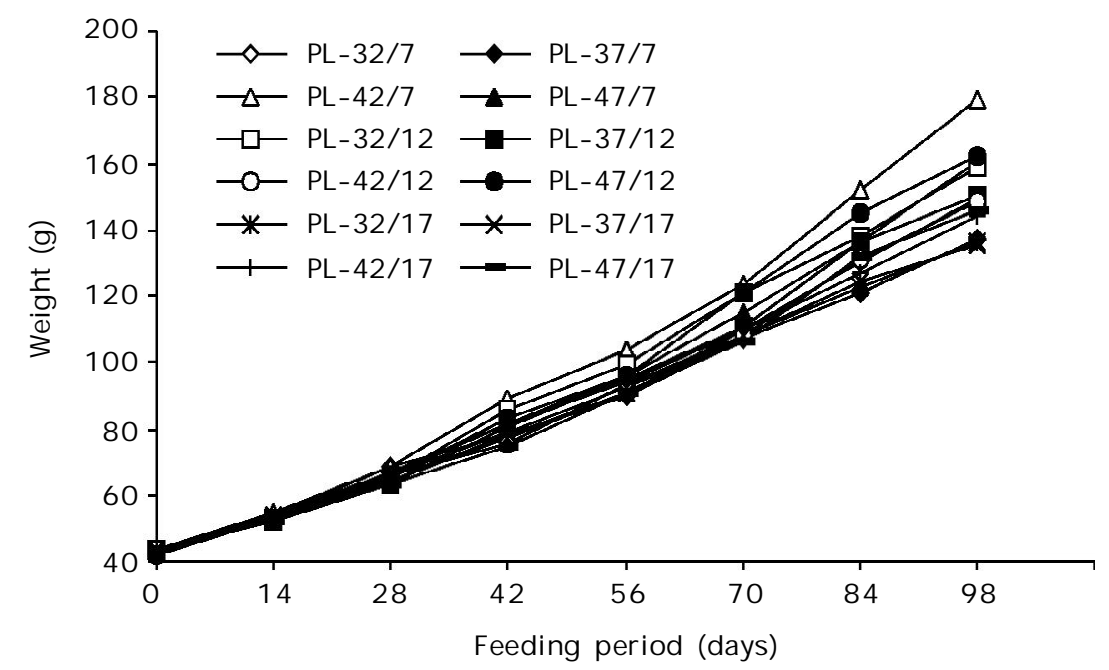

Figure 1. Growth of red snapper L. sebae fed with experimental diet for 98 days

Table 3. Final weight (Fw), weight gain (Wg), survival, feed intake (FI), and feed efficiency (FE) of red snapper L. sebae fed with experimental diet for 98 days $^{1}$

\begin{tabular}{|c|c|c|c|c|c|c|}
\hline $\begin{array}{l}\text { Dietary } \\
\text { Factors }\end{array}$ & Level & $\begin{array}{l}\text { Fw } \\
\text { (g) }\end{array}$ & $\begin{array}{l}\mathbf{W g}^{2} \\
(\%)\end{array}$ & $\begin{array}{c}\text { Survival } \\
(\%)\end{array}$ & $\begin{array}{c}\text { FI } \\
\text { (g/fish/day) }\end{array}$ & $\mathrm{FE}^{3}$ \\
\hline \multirow[t]{4}{*}{ Protein } & 32 & $147.0^{a}$ & $241.8^{a}$ & $80.7^{a}$ & $1.58^{\mathrm{a}}$ & $0.64^{\mathrm{ab}}$ \\
\hline & 37 & $142.1^{\mathrm{a}}$ & $229.1^{a}$ & $82.7^{a}$ & $1.68^{a}$ & $0.61^{a}$ \\
\hline & 42 & $157.4^{\mathrm{b}}$ & $265.1^{\mathrm{b}}$ & $76.7^{a}$ & $1.63^{a}$ & $0.69^{b}$ \\
\hline & 47 & $156.3^{b}$ & $267.1^{b}$ & $78.0^{a}$ & $1.61^{\mathrm{a}}$ & $0.67^{b}$ \\
\hline \multirow[t]{3}{*}{ Lipid } & 7 & $156.5^{x}$ & $262.8^{x}$ & $80.5^{x}$ & $1.66^{x}$ & $0.67^{x}$ \\
\hline & 12 & $155.0^{x}$ & $261.0^{x}$ & $79.5^{x}$ & $1.60^{x}$ & $0.68^{x}$ \\
\hline & 17 & $140.6^{y}$ & $225.9^{y}$ & $78.5^{x}$ & $1.62^{x}$ & $0.61^{y}$ \\
\hline
\end{tabular}

1 Initial weight $=43.1 \mathrm{~g}$. Values in column for each dietary factor with the same supersript are not significantly different $(P>0.05)$

$2 \mathrm{Wg}=$ (final weight - initial weight) $\times 100 /$ initial weight

3 Feed efficiency $=$ weight gain $(g) /$ total feed intake $(g)$

fat $(P>0.05)$. Feed consumption of fish for all treatments ranged of $1.58-1.68 \mathrm{~g} / \mathrm{fish} /$ day.

Variance analysis showed that the interaction effect of dietary protein and dietary lipid on the growth, feed consumption and feed efficiency of fish was not significantly different $(P>0.05)$. This data indicates that there is no protein-sparing effect on the red snapper fed on diet containing different protein and lipid contents. Catacutan et al. (2008) also reported there was no protein- sparing effect on the red snapper, L. argentimaculatus fed on diet with different dietary protein and dietary lipid levels. The same results was also reported for white sea bream, Diphedus sargus (Ozorio et al., 2006), yellow croaker, Pseudosciaena crocea (Duan et al., 2002), and humpback grouper, Cromileptes altivelis (Giri et al., 2002).

Williams et al. (2003) reported that the protein-sparing effect was significant on the small size perch, Lates calcarifer fed on diet with different dietary protein and lipid contents. 
Significant results on the influence of dietary lipid on the protein-sparing effect phenomena was also reported on dentex, Dentex dentex where protein content of diet can be reduced from $57 \%$ to $50 \%$ when the actual dietary energy was maintained at $22 \mathrm{~kJ} / \mathrm{g}$ with $19.7 \%$ of lipid (Skalli et al., 2004). Protein- sparing effect was also apparent in rockfish, Sebastes schlegeli, where feed with protein contents of $42 \%$ and lipid of $14 \%$ was optimal for fish growth (Lee et al., 2002). Increasing the level of dietary lipid from 15 to $22 \%$ in the diet were reported to increase the utilization protein on the gilthead sea bream, Sparus aurata indicating the protein-sparing effect (Vergara et al., 1999). Dietary protein content significantly influenced the growth parameters of red snapper (Table 3).

Regardless of the dietary lipid contents, final weight and percent weight gain of fish fed on diet with $42 \%$ protein content was higher and significantly different $(P>0.05)$ compared to fish fed on diet with $32 \%$ and $37 \%$ protein contents. However, increased dietary protein to the level of $47 \%$ did not improve the final weight and percent weight gain of fish. This data indicates that dietary protein of $42 \%$ is optimal for red snapper, L. sebae. While feed intake was not significantly different $(P>0.05)$ in all treatments (Table 3 ), difference in the growth of fish actually portrayed the response of different protein contents of the experimental diets. Analysis of the growth data from natural populations of red snapper, L. sebae indicates that the male grow faster than the female (Newman \& Dunk, 2002; McPherson \& Squire, 1992). Feed efficiency describes the proportion of feed that can be used for the growth of fish. Different levels of dietary protein in the experimental diets significantly affected feed efficiency of red snapper. Increased protein contents of experimental diet from $32 \%$ and $37 \%$ to $42 \%$ and $47 \%$ increase feed efficiency. The feed efficiency of fish fed on diet with protein content of $42 \%$ and $47 \%$ was not significantly different $(P>0.05)$. This results was in line with the growth data of fish fed on diet with $42 \%$ and $47 \%$ protein contents. Result of the present study indicated that the dietary protein requirement of red snapper, L. sebae of $42 \%$ was close to the data of protein requirement of another species of red snapper, L. argentimaculatus of $40 \%$ (Giri et al., 2007) and 44\%(Catacutan et al., 2008).
Different levels of dietary lipid significantly affected final weight, percent weight gain, and feed efficiency of fish. Growth and feed efficiency of fish fed on diet with lipid contents of $12 \%$ and $7 \%$ were the same and these growth values were significantly higher than the fish fed on diet with lipid content of $17 \%(P>0.05)$. These results indicated that red snapper $\mathrm{L}$. sebae has a limited ability in utilizing lipid as a source of energy and tends to use energy from dietary protein. Catacutan et al. (2008) reported that increased dietary lipid contents from $6 \%$ to $12 \%$ on each level of dietary protein of $35 \% 42.5 \%$ and $50 \%$ for red snapper, L. argentimaculatus did not increase fish growth. Wang et al. (2005) reported that reduced growth and feed intake were observed for cobia, Rachycentron canadum when fed with diet containing high lipid ( $25 \%$ compared to those fed with diet containing low lipid (5\%and $15 \%$ ). This data indicates that high lipid in diet can not be used effectively as a source of energy by the fish, as also reported by Williams et al. (2003) for sea bass, L. calcarifer. Besides as a source of energy, lipid is also required by fish to meet its essential fatty acid requirement and as the medium for fat soluble substances such as vitamins $A, D, E$, and $K$. In the experiment using malabar grouper, Epinephelus malabaricus Lin \& Shiau (2003) reported this grouper requires at least $4 \%$ lipid in its diet to produce good growth. Growth of this grouper species was significantly reduced when lipid content in diet was increased from 12\%to $16 \%$

Proximate composition of whole body fish after the feeding experiment was presented in Table 4. Variance Analysis showed that there was no significant interaction effect between dietary protein and lipid levels on dry matter, crude protein and ash content of fish. Regardless of the dietary lipid contents, different contents of dietary protein did not significantly affect dry matter, crude protein, lipid, and ash content of fish body ( $\mathrm{P}>0.05)$. Different protein contents of feed also were reported to have no significant effect on the protein contents of meat of yellow croaker, P. crocea (Duan et al., 2002), red snapper, L. argentimaculatus (Catacutan et al., 2008), and white sea bream D. sargus (Ozorio et al., 2006).

Differences in lipid contents of the experimental diet significantly affect the dry matter, crude protein, and lipid contents of whole body fish $(P<0.05)$. Fish that were fed with diet con- 
The effects of different levels of dietary protein ... (Nyoman Adiasmara Giri)

Table 4. Protein, lipid, and ash content of whole body of red snapper L. sebae fed on experimental diet for 98 days $^{1}$

\begin{tabular}{cccccc}
\hline $\begin{array}{c}\text { Dietary } \\
\text { factors }\end{array}$ & Level & $\begin{array}{c}\text { Dry matter } \\
\mathbf{( \% )}\end{array}$ & $\begin{array}{c}\text { Protein } \\
\mathbf{( \% )}\end{array}$ & $\begin{array}{c}\text { Lipid } \\
\mathbf{( \% )}\end{array}$ & $\begin{array}{c}\text { Ash } \\
\mathbf{( \% )}\end{array}$ \\
\hline Protein & 32 & $31.7^{\mathrm{a}}$ & $56.5^{\mathrm{a}}$ & $18.4^{\mathrm{a}}$ & $18.5^{\mathrm{a}}$ \\
& 37 & $31.8^{\mathrm{a}}$ & $57.1^{\mathrm{a}}$ & $18.3^{\mathrm{a}}$ & $19.1^{\mathrm{a}}$ \\
& 42 & $31.8^{\mathrm{a}}$ & $56.6^{\mathrm{a}}$ & $18.4^{\mathrm{a}}$ & $18.9^{\mathrm{a}}$ \\
& 47 & $31.3^{\mathrm{a}}$ & $57.2^{\mathrm{a}}$ & $18.3^{\mathrm{a}}$ & $19.0^{\mathrm{a}}$ \\
\hline Lipid & 7 & $30.3^{\mathrm{x}}$ & $58.3^{\mathrm{x}}$ & $16.2^{\mathrm{x}}$ & $18.7^{\mathrm{x}}$ \\
& 12 & $32.1^{\mathrm{y}}$ & $57.6^{\mathrm{x}}$ & $18.0^{\mathrm{y}}$ & $19.3^{\mathrm{x}}$ \\
& 17 & $32.6^{\mathrm{y}}$ & $54.7^{\mathrm{y}}$ & $20.8^{\mathrm{z}}$ & $18.6^{\mathrm{x}}$ \\
\hline
\end{tabular}

1 Values in the same column for each dietary factor with the same superscript are not significantly different $(P>0.05)$

taining high lipid contents ( $17 \%$ had the lowest body protein content. The same result was also reported for Striped bass, Morone saxatilis (Millikin, 1983). However, protein content of the meat of White Sea bream, D. sargus was reduced when lipid content of diet was increased (Ozorio et al., 2006). Lipid content of whole body of red snapper, L. sebae in the present study had increased following increasing of lipid content of diets. This data shows that red snapper, L. sebae has limited ability in utilizing lipid as a source of dietary energy, and the excess of lipid tends to be stored in the body of fish. The same result was also reported on the humpback grouper, C. altivelis, where fish fed on high lipid diet tended to have high body lipid content (Giri et al., 2002).

\section{CONCLUSION}

1. The best combination of protein and lipid levels in the diet of Red snapper, L. sebae was $42 \%$ and $12 \%$ respectively which was indicated by good growth and feed efficiency of tested fish.

2. Increasing the lipid content of the diet above $12 \%$ did not improve the growth of red snapper but instead leading to the increase of body lipid content of fish.

\section{REFERENCES}

AOAC (Association of Official Analytical Chemists). 1990. Official methods of analysis, 12th edition. Association of Official Analytical Chemists, Washington, D.C., 1,141 pp.
Catacutan, M.R., Pagador, G.E., \& Teshima, S. 2008. Effect of dietary protein and lipid levels and protein to energy ratios on growth, survival and body composition of the mangrove red snapper, Lutjanus argentimaculatus (Forsskal 1775). Aquaculture Research, 32(10): 811-818.

Duan, Q., Mai, K., Zhong, H., Si, L., \& Wang, X. 2002. Studies on the nutrition of the large yellow croacker, Pseudosciaena crocea R. I: growth response to graded levels of dietary protein and lipid. Aquaculture Research, 32(1): 46- 52.

Giri, N.A. 1998. Nutritional aspect for supporting breeding and seed production of grouper. Proc. "Seminar Teknologi Perikanan Pantai", Denpasar, 6-7 August 1998. Collaboration between Center Research Institute for Fisheries and Japan International Cooperation Agency (IICA), p. 44- 51. (in Indonesian, English abstract).

Giri, N.A., Suwirya, K., \& Marzuqi, M. 2002. Effect of dietary protein and energy on growth of juvenile humpback grouper (Cromileptes altivelis). Indonesian Fisheries Research Journal, 8: 5- 9.

Giri, N.A., Suwirya, K., Pithasari, A.I., \& Marzuqi, M. 2007. Effect of dietary protein levels on growth and feed efficiency of juvenile red snapper (Lutjanus argentimaculatus). Journal of Fisheries Sciences, IX(1): 55-62. (in Indonesian, English abstract).

Imanto, P.T. \& Melianawati, R. 2003. Early development of the larvae red emperor, Lutjanus sebae. J.Penelitian Perikanan In- 
donesia, 9(1): 11- 19. (in Indonesian, English abstract).

Lee, S., Jeon, I.G., \& Lee, J.Y. 2002. Effects of digestible protein and lipid levels in practical diets on growth, protein utilization and body composition of juvenile rockfish (Sebastes schlegeli). Aquaculture, 211(1-4): 227- 239.

Lin, Y. \& Shiau, V. 2003. Dietary lipid requirement of grouper, Epinephelus malabaricus, and effects on immune responses. Aquaculture, 225(1-4): 1- 4.

Luo, Z., Liu, Y.J., Mai, K.S., Tian, L.X., Liu, D.H., \& Tan, X.Y. 2004. Optimum dietary protein requirement of grouper Epinephelus coioides juveniles fed isoenergetic diets in floating net cages. Aquaculture Nutrition, 10: 247- 252.

McPherson, G.R. \& Squire, L. 1992. Age and growth of three dominant Lutjanus species of the Great Barrier Reef Inter- Reef Fishery. Asian Fisheries Science, 5: 25- 36.

Melianawati, R. \& Imanto, P.T. 2004. Feeding preference on live feed of emperor snapper larvae Lutjanus sebae. J. Penelitian Perikanan Indonesia, 10(1): 21- 24. (in Indonesian, English abstract).

Millikin, M.R. 1983. Interactive effects of dietary protein and lipid on growth and protein utilization of age- 0 striped bass. Transaction of American Fisheries Society, 112: 185- 193.

Newman, S.J. \& Dunk, I.J. 2002. Growth, age validation, mortality, and other population characteristics of the emperor red snapper, Lutjanus sebae (Cuvier, 1828), off the Kimberley Coast of North- Western Australia. Estuarine, Coastal and Shelf Science, 55(1): 67- 80.

Ozorio, R.O.A., Valente, L.M.P., Pousao- Ferreira, P., \& Oliva-Teles, A. 2006. Growth perfor- mance and body composition of white seabream (Diplodus sargus) juveniles fed diets with different protein and lipid levels. Aquaculture Research, 37(3): 255- 263.

Skalli, A., Hidalgo, M.C., Abellan, E., Arizcun, M., $\&$ Cardenete, G. 2004. Effect of dietary protein/ lipid ratio on growth and nutrient utilization in common dentex (Dentex dentex L.) at different growth stages. Aquaculture, 235(1- 4): 1- 11.

Steel, R.G.D. \& Torrie, J.H. 1980. Principles and procedures of statistics. McGraw Hill, New York, USA, 481 pp.

Suwirya, K., Giri, N.A., Sutarmat, T., \& Marzuqi, M. 2008. Feed development and application for golden trevally (Gnathanodon speciosus). In H. Supriyadi, A. Hanafi, A.H. Kristanto, Chumaidi, A. Mustafa, Imron and I. Insan (Eds.): Teknologi Perikanan Budidaya. Center Research for Aquaculture, Jakarta,. p. 315- 320. (in Indonesian, English abstract).

Vergara, J.M., Lopes- Calero, G., Robaina, L., Caballero, M.J., Izquierdo, M.S., \& Aksnes, A. 1999. Growth, feed utilization and body lipid content of gilthead seabream (Sparus aurata) fed increasing lipid levels and fish meals of different quality. Aquaculture, 179(1-4): 35- 44.

Wang, J., Liu, Y., Tian, L., Mai, K., Du, Z., Wang, Y., $\&$ Yang, H. 2005. Effect of dietary level on growth performance, lipid deposition, hepatic lipogenesis in juvenile cobia (Rachycentron canadum). Aquaculture, 249(1- 4): 439- 447.

Williams, K.C., Barlow, C.G., Rodgers, L., Hockings, I., Agcopra, C., \& Ruscoe, I. 2003. Asian seabass Lates calcarifer perform well when fed pelleted diets high in protein and lipid. Aquaculture, 225(1-4): 191- 206. 